\title{
Interacting effects of wave exposure, tidal height and substratum on spatial variation in densities of mussel Perna perna plantigrades
}

\author{
C. D. McQuaid*, J. R. Lindsay \\ Department of Zoology and Entomology, Rhodes University, Grahamstown 6140, South Africa
}

\begin{abstract}
A fine time-scale study was undertaken on the effects of wave exposure, tidal height and substratum type on mussel recruit densities on the south coast of South Africa. Prior to sampling, an exposed and a sheltered shore were identified at each of 2 sites (Diaz Cross and High Rocks) $7 \mathrm{~km}$ apart. Each shore was divided into 3 shore levels (termed zones) within which 3 substrata (adult mussels, coralline and non-coralline macroalgae) were sampled. Destructive sampling of early $(<1 \mathrm{~mm})$ and late $(1$ to $5 \mathrm{~mm}$ ) plantigrades was performed daily over $30 \mathrm{~d}$ during a period of comparatively high recruitment. Recruitment was synchronised among substrata within zones, but not among zones or between sites. This suggests that larvae will settle on all substrata within a zone, but will prefer some substrata over others. They will not, however, search among zones for favoured substrata. Densities of early (but not late) plantigrades were consistently greater at Diaz Cross than High Rocks, indicating important differences in post-settlement mortality between sites. At both sites, densities of both recruit classes were greater on the low and mid shore than on the high shore. Generally (18 out of 20 comparisons), plantigrade densities within each zone were greater on algae than on adult mussels. Approximately $45 \%$ of all recruits collected were found on the foliose coralline alga Corallina, $37 \%$ on adult mussels and $18 \%$ on the rhodophyte Gelidium pristoides. Without secondary relocation from macroalgae to adult mussel beds, juveniles recruiting onto algae are likely to be lost. On low shore algae, densities of both early and late plantigrades were greater for exposed shores. Densities of plantigrades on the mussel bed and on algae on the mid and high shore were not correlated with exposure. Thus, site, substratum and zone all had significant and interacting effects on the density of recruits on both exposed and sheltered shores. The effect of wave exposure on recruitment, at least on the low shore, suggests that spatial subsidies not only in the form of food supply, but also in the form of larval transport, have a role in structuring mussel populations.
\end{abstract}

KEY WORDS: Perna perna $\cdot$ Rocky shores $\cdot$ Recruitment $\cdot$ Settlement

\section{INTRODUCTION}

Mussel populations are strongly shaped by the interactions of predation, competition and recruitment. Menge \& Sutherland $(1976,1987)$ view predation and competition as complementary, with the balance between them depending on the interaction between recruitment intensity and predation rates. Certainly, while the effects of predation are clear in many cases (e.g. Paine 1974, Robles et al. 1990, Robles \& Robb 1993), its importance differs biogeographically be- tween low and high recruitment regimes (Menge \& Lubchenco 1981). Moreover, these biological effects interact not only with each other, but also with the physical environment. For example, predators may be less abundant or less efficient under strongly waveexposed conditions (Menge 1974, 1976, Menge \& Sutherland 1976, though see Menge 1992), while growth rates differ along physical gradients such as low to high shore (Griffiths 1981), salinity gradients in the Baltic Sea (Westerbom et al. 2002), or between exposed and sheltered conditions (Menge 1992, 
McQuaid \& Lindsay 2000). Griffiths \& Hockey (1987) have modelled predation versus intraspecific competition as causes of mortality and find the balance shifts depending on growth rates. Thus, the importance of competition for space differs between high and low shore mussel populations or between exposed and sheltered populations because of direct effects on mussel growth and non-predatory mortality rates (e.g. Kitching et al. 1958, Dayton 1971, Menge 1976, McQuaid \& Lindsay 2000), as well as indirect effects on predators. As a result, the population structure of mussel beds can differ markedly between wave-exposed and wave-sheltered shores (Jones \& Demetropoulos 1968, Alvarado \& Castilla 1996, McQuaid et al. 2000).

Recruitment is determined by settlement rates and post-settlement mortality. Settlement depends on factors operating at a range of physical scales, including larval supply and delivery as well as larval behaviour that allows choice of substratum (Petersen 1984, Nielsen \& Franz 1995). Supply will have a biogeographic component, but within a given area, hydrodynamic processes can regulate the supply of larvae reaching potential settling sites (Armonies \& Hellwig-Armonies 1992, Fuentes \& Molares 1994, Leonard et al. 1998, Cowen et al. 2000, McCulloch \& Shanks 2003). Likewise, advection of water/larvae to a site and water flux over a site can influence the number of settlers (Hunt \& Scheibling 1995, Judge \& Craig 1997, Leonard et al. 1998). This implies potential differences in larval supply to wave-exposed as opposed to sheltered sites, and to high as opposed to low shore zones (e.g. McKindsey \& Bourget 2000). Accordingly, the proportion of variability in adult densities explained by recruitment appears to decline from exposed to sheltered sites (Menge \& Farrell 1989). In addition, properties of the existing community on the shore can affect settlement. On one hand, the presence of macroalgae can increase the density of mussel settlers in a given area (CáceresMartínez et al. 1993, 1994, Phillips 1994, Davis \& Moreno 1995), while on the other, filtering of larvae by adult mussels may be important (Andre et al. 1993, Lehane \& Davenport 2004).

As well as settlement intensity, recruitment (i.e. the number of juveniles surviving to some point in time after settlement) also depends on subsequent mortality rates. There is little information on predation of recent settlers. Hunt \& Scheibling (1998) suggest that predation of mussels $>2$ to $3 \mathrm{~mm}$ by young whelks may influence recruitment but there is no evidence that predation of early plantigrades (i.e. individuals $<1 \mathrm{~mm}$ ) is important on rocky shores. On soft sediments, crustaceans often prey on bivalve spat. Van der Veer et al. (1998) concluded that such predation does not appear to limit recruitment, but Beukema \& Dekker (2005) attribute long-term (15 yr) declines in Wadden Sea bivalve numbers largely to predation of the early benthic stages. There is also little or no information on competition for space among recent settlers, although the stochastic development of new beds in areas previously devoid of mussels (Berry 1978, C. D. McQuaid pers. obs.) suggests that this may occasionally be important, and competition for space certainly becomes a major source of mortality at later stages (Griffiths \& Hockey 1987, Hughes \& Griffiths 1988). Mortality of recent settlers is, however, likely to be affected by abiotic factors such as dislodgement by waves, desiccation and/or temperature stress, which are linked to height on the shore and degree of wave exposure.

An important peculiarity of mussels is that their recruitment may also be affected by secondary settlement. Bayne (1964) suggested that Mytilus exhibits secondary relocation of plantigrades from an initial settlement site of algae into adult mussel beds. There has been support for this suggestion (e.g. Seed 1969), but there is little direct evidence (see below) and Lasiak \& Barnard (1995) suggest that Perna perna, the dominant mussel on the south and east coasts of South Africa, does not exhibit such behaviour. The fate of juvenile Perna settling onto algae is unclear and a secondary dispersal phase raises the possibility of further loss of recruits through advection or failure to find suitable settlement sites etc. However, without re-location in some form, larvae on algae are presumably lost to the population. This is particularly important on the south and east coasts of South Africa because, although disturbance by wave action can be an important cause of mortality (J. Erlandsson unpubl. data), predators other than man seem to exert little control on mussel populations (Griffiths \& Hockey 1987) and mussel beds on this coast appear to be strongly recruitment-limited (Berry 1978, Harris et al. 1998, C. D. McQuaid \& T. E. Phillips unpubl. data). The question of possible secondary settlement is especially important because small mussels are often abundant on a common macroalgae, the rhodophyte Gelidium pristoides, which is harvested commercially (Beckley 1979, Erlandsson \& McQuaid 2004).

Thus, recruitment holds the balance between competition and predation as major regulators of mussel populations. Recruitment rate, in turn, is clearly affected by wave exposure, height on the shore and substratum type, but it is clear from the literature that their effects are not consistent and we are not aware of any study that examines them simultaneously. Here, we examine the interactions of the effects of these 3 factors on densities of early recruits of Perna perna sampled on a fine temporal scale. In particular, we address the issue of whether juvenile mussels on algae form a significant proportion of early recruitment. 


\section{MATERIALS AND METHODS}

\section{Study sites}

The densities, distribution and sizes of Perna perna recruits were quantified at 2 sites approximately $7 \mathrm{~km}$ apart, near Kenton-on-Sea $\left(33^{\circ} 41^{\prime} \mathrm{S}, 2^{\circ} 40^{\prime} \mathrm{E}\right)$ on the south coast of South Africa. Both sites were of aeolianite rock, in the form of wave-cut platforms, with mussel beds at the seaward edge of the platform. At each site, we identified 1 exposed and 1 sheltered shore $<150 \mathrm{~m}$ apart. Exposed sites were on headlands with heavy wave action, waves breaking onto or just before the mussel bed. sites were in the lee of headlands, where waves break further offshore and roll onto the rocks as white water. The shores sampled were Diaz Cross exposed (DE) and sheltered (DS), and High Rocks exposed (HE) and sheltered (HS).

At each shore, we sampled the low, mid and high shore regions of mussel beds, which we termed 'zones'. Within each zone, we sampled 2 substrata: (1) adult mussel beds and (2) foliose macroalgae. Algae comprised the articulated coralline algae Corallina spp. on the low shore and the non-coralline red alga Gelidium pristoides on the mid and upper shore. Recently settled Perna perna have been observed on all of these substrata (Berry 1978, Beckley 1979, Lasiak \& Barnard 1995). At sheltered low shore sites, mussels were so scarce that it was not practical to sample them (Table 1).

\section{Sampling procedure}

Daily sampling was undertaken from 20 April 1996 to 21 May 1996. Sampling took too long and sites were too inaccessible to allow sampling of both sites on the same

Table 1. Mean percentage cover $( \pm \mathrm{SD})$ of settlement substrata in each zone on each shore. E: exposed; S: sheltered sites; -: absence of a substratum

\begin{tabular}{|lcccc|}
\hline Shore & Zone & Coralline & Mussel & Gelidium \\
\hline Diaz Cross E & Low & $68.6(18.6)$ & $61.1(17.4)$ & - \\
& Mid & - & $15.4(7.5)$ & $20.1(8.9)$ \\
& High & - & $17.1(5.4)$ & $14.0(2.0)$ \\
Diaz Cross S & Low & $94.6(6.9)$ & $1.0(1.3)$ & - \\
& Mid & - & $16.6(5.7)$ & $1.9(1.5)$ \\
& High & - & $18.6(6.6)$ & $17.4(6.8)$ \\
High Rocks E & Low & $56.4(16.1)$ & $61.3(19.6)$ & - \\
& Mid & & $20.7(4.4)$ & $8.1(3.5)$ \\
& High & - & $16.3(5.1)$ & $6.7(2.8)$ \\
High Rock S & Low & $84.0(12.0)$ & $1.3(0.6)$ & - \\
& Mid & - & $30.9(10.1)$ & $14.6(19.0)$ \\
& High & - & $5.3(1.7)$ & $6.5(1.8)$ \\
\hline
\end{tabular}

day. Thus, sites were sampled on alternate days, but sampling was sometimes impossible because of conditions of tide and weather. The temporal resolution of sampling decreased down shore as the low shore was more often inaccessible, especially during neap tides.

Recruitment was examined by clearing 3 randomlyplaced $10 \times 10 \mathrm{~cm}$ quadrats with $100 \%$ cover of each substratum within each tidal height. The entire area of each substratum within a quadrat was removed and the rock scraped bare of visible organisms. Samples were placed in $12 \%$ commercial bleach solution (sodium hypochlorite) for 5 to $10 \mathrm{~min}$ and agitated to release young mussels from the substratum (Davies 1974). The substratum and solution were then washed through a series of sieves $(500,300,150 \mu \mathrm{m})$ and the material left in the top sieve was thoroughly rinsed with water. Mussels less than $15 \mathrm{~mm}$ were washed into filter paper funnels and frozen. Later, all mussels were counted and measured (to the nearest $0.083 \mathrm{~mm}$ ) using a dissecting microscope fitted with a micrometer. Large amounts of sand or numbers of mussels made it necessary to process subsamples (50 or $25 \%$ ), obtained using a plankton splitter, in a few (8) cases. Perna perna settles at a size of 300 to $320 \mu \mathrm{m}$, and individuals $>340 \mu \mathrm{m}$ show growth of the dissoconch (S. Bownes unpubl. data). We divided samples into early $(<1 \mathrm{~mm})$ and late ( 1 to $5 \mathrm{~mm}$ ) plantigrades. Thus, early plantigrades include primary settlers that have just arrived on the shore as well as individuals that settled some time previously.

The percentage cover of each substratum on each shore was estimated visually using ten $50 \times 50 \mathrm{~cm}$ quadrats, sub-divided into $100 \mathrm{~cm}^{2}$ squares, placed at random in each zone (Table 1).

\section{Data analysis}

Synchrony of recruitment. Trends in daily recruit densities were examined with reference to site, substratum and zone. Our approach was subjective and limited to obvious trends, as formal analysis (e.g. using cross-correlation) would have required the data to be so reduced that little information would have been gained. Observations were divided into 2 broad categories: (1) synchrony on a given substratum in different zones and (2) synchrony among substrata within zones. This was done for Diaz Cross and High Rocks data independently and separately for early and late plantigrades.

Density. Analyses of densities were carried out separately for early and late plantigrades. Ideally, the data would be analysed in a 4 -way ANOVA, using site, substratum, zone and exposure as the factors. However, the design was incomplete as mussels were so rare at 
sheltered low shore sites that it was not possible to sample them. In addition, data were missing for some days when sampling was impossible. Therefore, the analysis was done in 4 sections, using data pooled for the entire period. Analyses were carried out using Statgraphics (v.7.0) software on untransformed data, unless transformations improved the suitability of the data for ANOVA. Post hoc tests were done using Tukey's test. Due to the large number of 1-way ANOVAs performed in the final analyses, Bonferroni adjustments were undertaken to avoid Type 1 errors (see below).

Effects of site, zone and exposure on recruit densities on algae: The densities of plantigrades on algae were examined with a 3-way ANOVA using site (DC, $\mathrm{HR})$, exposure $(\mathrm{E}, \mathrm{S})$ and zone (low, mid, high) as factors. For this analysis, Corallina and Gelidium were not distinguished from each other, and were treated together as algae because they predominate in different zones, confounding zone with algal species. The analyses were carried out on log-transformed data $(\log x+1)$.

Effects of site, zone and substratum on recruit densities under exposed conditions: A 3-way ANOVA was carried out using site (DC, HR), zone (low, mid, high) and substratum (mussels, algae) as factors. The analyses were carried out on log-transformed data (log $x+1$ ). This analysis could not be performed for the sheltered shores because the substratum 'low shore mussels' was missing.

Effects of site, zone, exposure and substratum on the mid and high shore: The effects of site (DC, HR), exposure (E, S), zone (mid, high) and substratum (mussels, algae) on plantigrade densities were examined using a 4-way ANOVA. The analyses were carried out on log-transformed data $(\log x+1)$.

Comparison of recruit densities on algae and mussels: Comparison of plantigrade densities on algae and mussels in each zone, and for each exposure was carried out using 1-way ANOVA. For each exposed shore, three 1-way ANOVAs were completed, 1 comparison for each zone. For sheltered shores, mussels were missing from the bottom of the shore and two 1-way ANOVAs were carried out, one each for the mid and highshore. Analyses were performed separately for early and late plantigrades, involving 20 ANOVAs, carried out with Bonferroni correction. These analyses were carried out on untransformed data.

The above analyses apply to areas of $100 \%$ cover of substratum, either algae or mussels. Densities of plantigrades on a theoretical square metre of shore, with a mixture of substrata, were estimated using the \% cover of substrata for each zone at each shore (Table 1). Comparisons of total plantigrade densities on each substratum were made for each zone at each shore using 1-way ANOVA of untransformed data, with Bonferroni correction.

\section{RESULTS}

\section{Synchrony of recruitment}

There are 3 aspects to synchrony: (1) between sites, (2) among substrata, (3) among zones. No strong temporal patterns were obvious and there were exceptions to the general patterns described below.

Densities of recruits were poorly synchronised between sites (Figs. 1 \& 2). At Diaz Cross, relatively high numbers of both size classes of recruits tended to occur between 2 to 7 May, with no obvious pattern at High Rocks. Likewise, there was little synchrony among zones and recruit densities were rarely synchronised on the same substratum in different zones on a shore. There was better synchrony among substrata within each zone, especially for early recruits. Synchrony among substrata deteriorated further upshore and did not occur on the high shore. Three

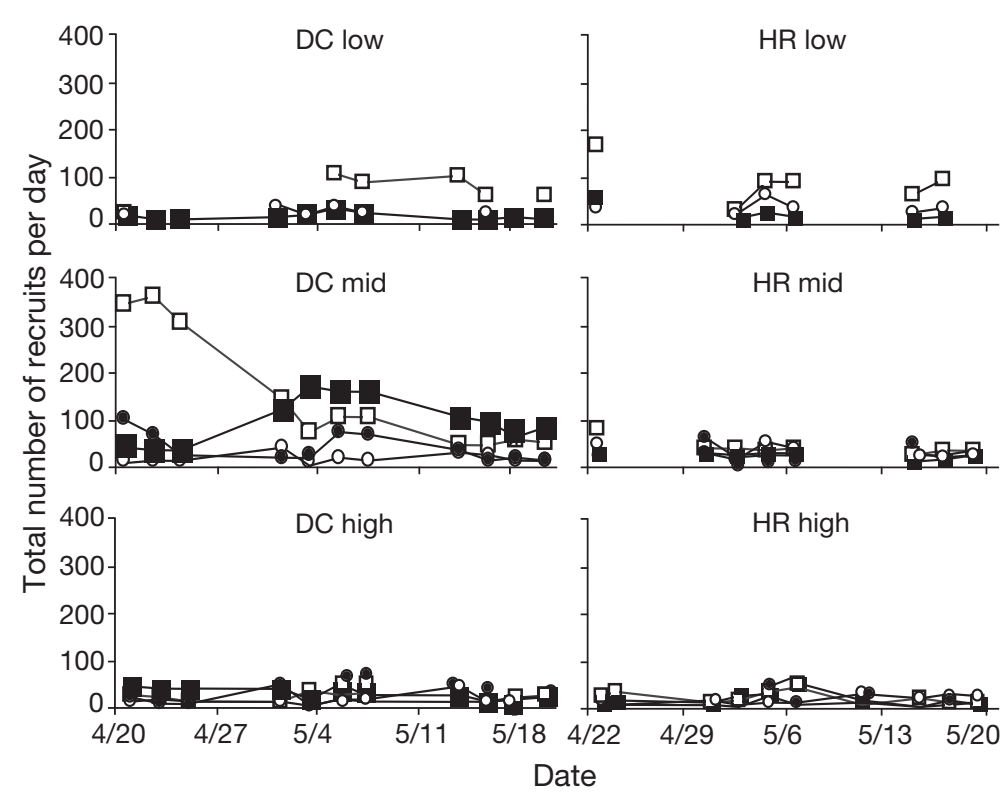

Fig. 1. Numbers of early plantigrades $(<1 \mathrm{~mm})$ on exposed and sheltered shores at low, mid and high zones, and on all substrata. Each point represents the total number of plantigrades collected on that day. DC: Diaz Cross; HR: High Rocks; $\bullet, O$ : mussels; $\mathbf{\square}, \square$ : algae; closed symbols: sheltered; open symbols: exposed 


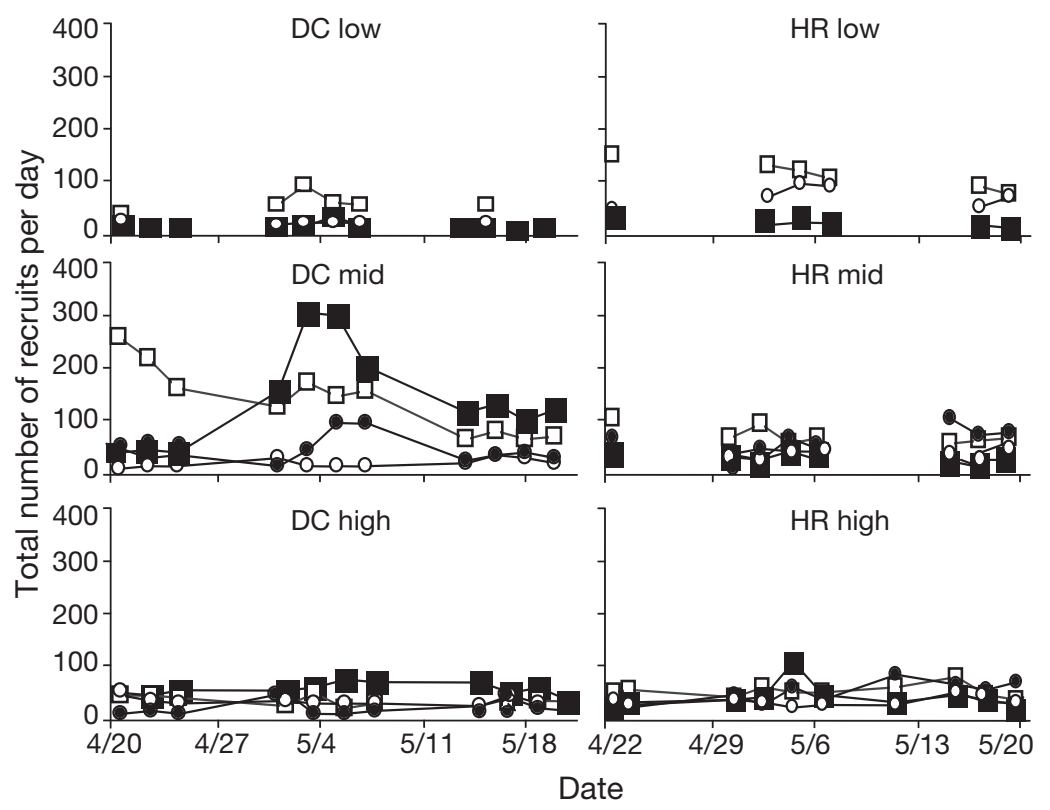

Fig. 2. Numbers of late plantigrades (1 to $4.99 \mathrm{~mm}$ ) on exposed and sheltered shores at low, mid and high zones, and on all substrata. Each point represents the total number of plantigrades collected on that day. DC: Diaz Cross; HR: High Rocks;, , O: mussels; $\square, \square$ : algae; closed symbols: sheltered; open symbols: exposed

cases of relatively good synchrony were (1) DS early recruits on the mid shore, (2) late recruits on the mid shore and (3) HE early recruits on the low shore (Figs. 1 \& 2).

\section{Density}

In all analyses, main effects were rare, but many interactions were significant.

Effects of site, zone and exposure on recruit densities on algae: Early plantigrades (Table 2A). Densities of early plantigrades were higher at Diaz Cross, but there was a significant site/zone interaction. At Diaz Cross, density was greatest on the mid shore, while at High Rocks it was greatest on the low shore (Fig. 3A). Densities tended to be greater on exposed shores, but at both sites, the difference in densities at exposed and sheltered shores decreased upshore, giving a significant interaction between exposure and zone (Fig. 3B).

Late plantigrades (Table $2 B$ ). The effect of zone differed between sites (interaction, $\mathrm{p}<0.0001$ ) and, as with early plantigrades, densities were greatest on the mid shore at Diaz Cross and on the low shore at High Rocks (Fig. 4A). Again, late plantigrades were more abundant under exposed conditions at both sites (site/exposure interaction non-significant, Fig. 4B), but there was a significant site/zone/ exposure interaction as the strength of exposure/zone interaction differed between sites (Fig. 2).
Effects of site, zone and substratum on recruit densities under exposed conditions: There were significant interactions among all factors in both analyses, indicating complex and variable effects.

Early plantigrades (Table 3A). Most interactions were significant, including all those involving site. Densities were significantly higher on algae than on mussels at both sites (Fig. 5A), but the effect was stronger at Diaz Cross (significant interaction of site and substratum). This effect was consistent across zones (Fig. 5B), with no zone/substratum interaction. There was a site/zone interaction, with higher densities on the low shore at High Rocks and the mid shore at Diaz Cross (Fig. 5C), as above. The significant site/zone/substratum interaction reflects the stronger effect of substratum at Diaz Cross and the differing effect of zone at the 2 sites.

Late plantigrades (Table 3B). The overall results were almost identical to those for early plantigrades, again with most interactions being significant; the only difference was a significant effect of site as a main factor. As for early plantigrades, greater densities were found on algae at both sites (Fig. 5D), though the interaction between site and substratum was significant. Although

Table 2. Three-way ANOVA showing effects of site, zone and exposure on densities of larvae on algae. ns: non-significant

\begin{tabular}{|lcccc|}
\hline Source of variation & df & MS & $F$ & $\mathrm{p}$ \\
\hline A. Early plantigrades & & & & \\
Site (Si) & 1 & 1.2511 & 23.889 & $\mathrm{p}<0.0001$ \\
Zone (Z) & 2 & 0.3374 & 0.29 & $\mathrm{~ns}$ \\
Exposure (E) & 1 & 1.9149 & 26.23 & $\mathrm{~ns}$ \\
Interactions & & & & \\
Si $\times$ Z & 2 & 1.1693 & 22.32 & $\mathrm{p}<0.0001$ \\
$\mathrm{Si} \times \mathrm{E}$ & 1 & 0.0730 & 1.39 & $\mathrm{~ns}$ \\
$\mathrm{Z} \times \mathrm{E}$ & 2 & 0.8617 & 34.06 & $\mathrm{p}<0.05$ \\
$\mathrm{Si} \times \mathrm{Z} \times \mathrm{E}$ & 2 & 0.0253 & 0.48 & $\mathrm{~ns}$ \\
Residual & 95 & 0.0524 & & \\
Total & 106 & & & \\
B. Late plantigrades & & & & \\
Site (Si) & 1 & 0.0048 & 0.10 & $\mathrm{~ns}$ \\
Zone (Z) & 2 & 1.5035 & 0.67 & $\mathrm{~ns}$ \\
Exposure (E) & 1 & 4.7225 & 74.84 & $\mathrm{~ns}$ \\
Interactions & & & & \\
Si $\times$ Z & 2 & 2.2574 & 47.22 & $<0.0001$ \\
Si $\times \mathrm{E}$ & 1 & 0.0631 & 1.32 & $\mathrm{~ns}$ \\
Z $\times \mathrm{E}$ & 2 & 2.6355 & 5.03 & $\mathrm{~ns}$ \\
Si $\times$ Z $\times$ E & 2 & 0.5244 & 10.97 & $<0.0001$ \\
Residual & 95 & 0.0478 & & \\
Total & 106 & & & \\
\hline
\end{tabular}



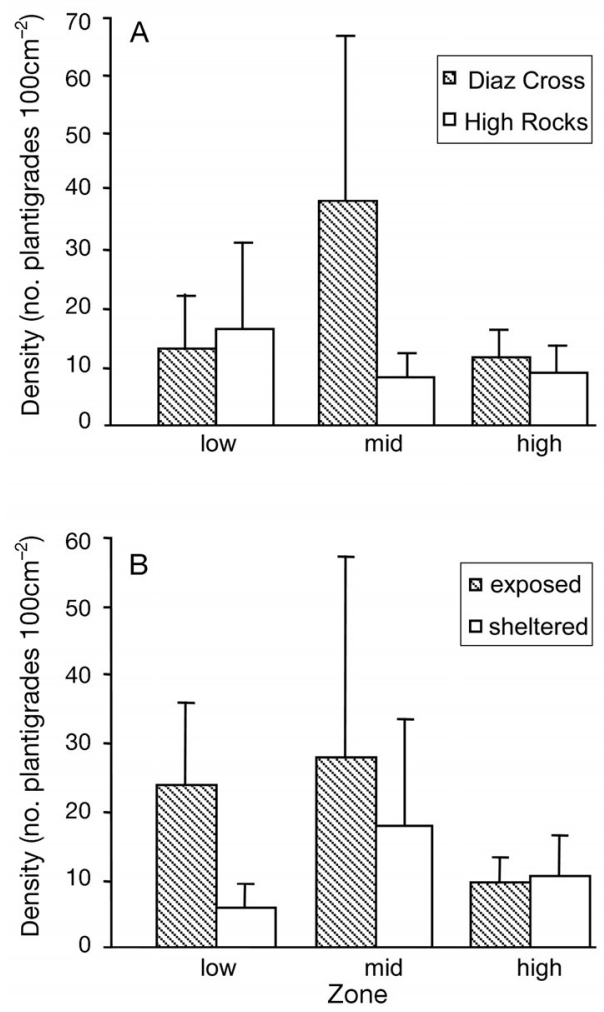

Fig. 3. Mean density $(+\mathrm{SD})$ of early plantigrades $(<1 \mathrm{~mm})$ on algae. (A) Data pooled for sites and zones. (B) Data pooled for degree of exposure and zones

the substratum effect appeared strongest on the mid shore (as for early plantigrades), there was no significant zone/substratum interaction (Fig. 5E). Again, as for early plantigrades, the effect of zone differed between sites; highest densities were on the mid shore at Diaz Cross, but on the low shore at High Rocks (Fig. 5F).

Effects of site, exposure, zone and substratum on the mid and high shore: The only significant main effect was the influence of site on early plantigrades (Table 4A,B), with higher densities at Diaz Cross, but there were a number of significant interactions, all involving site. The site/zone and site/substratum interactions were significant in both analyses, as were the 3-way interactions among site, zone and substratum. However, for both size classes, densities were always greater on algae than on mussels and on mid than high shore zones.

Summary of above analyses: Early and late plantigrades showed broadly the same statistical responses to the factors examined, with 1 important difference. Densities of early plantigrades were higher at Diaz Cross than they were at High Rocks, while for late plantigrades, there was generally no difference. More recruits occurred on the low and mid shore than on the
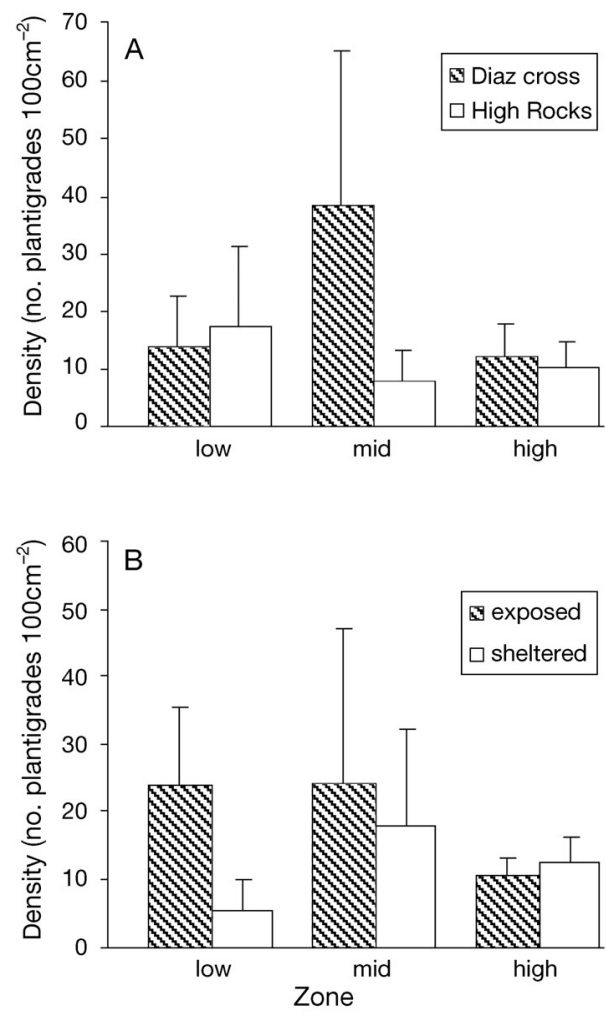

Fig. 4. Mean density (+SD) of late plantigrades (1 to $4.99 \mathrm{~mm}$ ) on algae. (A) Data pooled for sites and zones. (B) Data pooled for degree of exposure and zones

Table 3. Three-way ANOVA showing effects of site, zone and substratum on densities of larvae on exposed shores. ns: non-significant

\begin{tabular}{|lcccc|}
\hline Source of variation & df & MS & $F$ & $\mathrm{p}$ \\
\hline A. Early plantigrades & & & & \\
Site (Si) & 1 & 0.0162 & 3.02 & $\mathrm{~ns}$ \\
Zone (Z) & 2 & 0.2996 & 1.29 & $\mathrm{~ns}$ \\
Substratum (Su) & 1 & 2.6122 & 5.38 & $\mathrm{~ns}$ \\
Interactions & & & & \\
Si $\times$ Z & 2 & 0.2332 & 4.36 & $<0.05$ \\
Si $\times$ Su & 1 & 0.4857 & 9.09 & $<0.01$ \\
Z $\times$ Su & 2 & 0.3375 & 1.35 & $\mathrm{~ns}$ \\
Si $\times$ Z $\times$ Su & 2 & 0.2502 & 4.68 & $<0.05$ \\
Residual & 89 & 0.0535 & & \\
Total & 100 & & & \\
B. Late plantigrades & & & & \\
Site $(\mathrm{Si})$ & 1 & 1.0040 & 44.42 & $<0.0001$ \\
Zone (Z) & 2 & 0.2286 & 0.50 & $\mathrm{~ns}$ \\
Substratum (Su) & 1 & 2.6071 & 5.47 & $\mathrm{~ns}$ \\
Interactions & & & & \\
Si $\times$ Z & 2 & 0.4551 & 20.14 & $<0.0001$ \\
Si $\times$ Su & 1 & 0.4769 & 21.10 & $<0.0001$ \\
Z $\times$ Su & 2 & 0.5916 & 2.63 & $\mathrm{~ns}$ \\
Si $\times$ Z $\times$ Su & 2 & 0.2248 & 9.94 & $<0.0001$ \\
Residual & 89 & 0.0226 & & \\
Total & 100 & & & \\
\hline & & & & \\
\hline
\end{tabular}



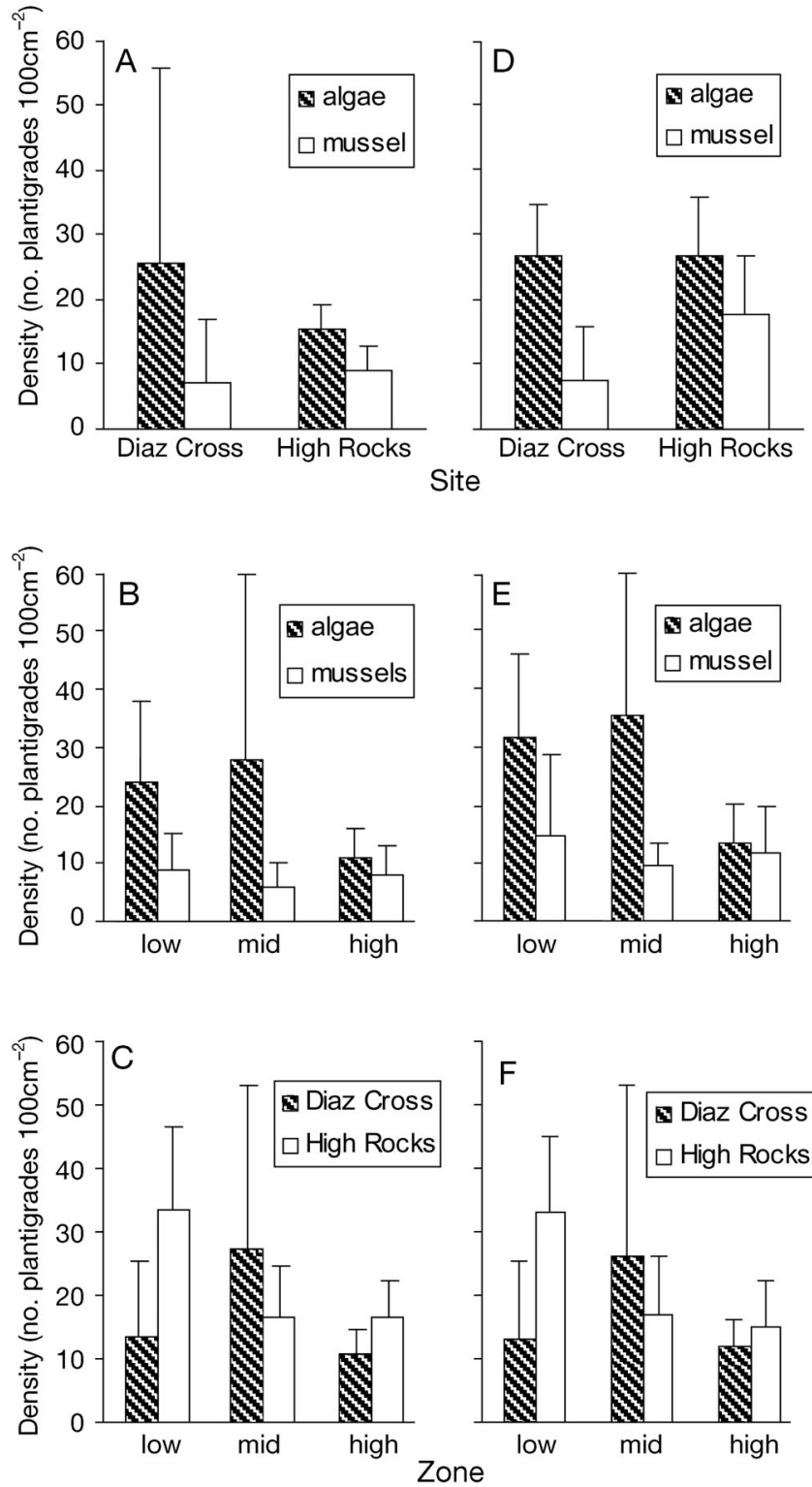

Fig. 5. Mean density (+SD) of early $(A-C)$ and late (D-E) plantigrades. (A) and (D) Data pooled for substrata and sites. (B) and (E) Data pooled for substrata and zones. (C) and (F) Data pooled for sites and zones

high shore, and on algae than on mussels. Plantigrade densities on low shore algae were greater under exposed conditions.

Effect of substratum at each exposure, zone and site: We compared the average numbers of plantigrades on $100 \%$ cover of algae or mussels at each exposure, in each zone (except for low shore) and at each site separately. Densities of early plantigrades were greater on algae in 9 out of 10 cases, but only 1 of these was significant (1-way ANOVA, p < 0.005) after Bonferroni adjustment. Densities of late plantigrades were also
Table 4. Four-way ANOVA showing effects of site, exposure, zone and substratum on densities of larvae on the mid and high shore. ns: non-significant

\begin{tabular}{|c|c|c|c|c|}
\hline Source of variation & df & MS & $F$ & $\mathrm{p}$ \\
\hline \multicolumn{5}{|c|}{ A. Early plantigrades } \\
\hline Site (Si) & 1 & 2914.2256 & 21.60 & $<0.0001$ \\
\hline Exposure (E) & 1 & 142.8946 & 14.688 & ns \\
\hline Zone (Z) & 1 & 1879.0197 & 0.96 & $\mathrm{~ns}$ \\
\hline Substratum (Su) & 1 & 2951.8405 & 1.36 & ns \\
\hline \multicolumn{5}{|l|}{ Interactions } \\
\hline $\mathrm{Si} \times \mathrm{E}$ & 1 & 9.7286 & 0.07 & $\mathrm{~ns}$ \\
\hline $\mathrm{Si} \times \mathrm{Z}$ & 1 & 1958.4260 & 14.52 & $<0.001$ \\
\hline $\mathrm{Si} \times \mathrm{Su}$ & 1 & 2177.6120 & 16.14 & $<0.0001$ \\
\hline $\mathrm{E} \times \mathrm{Z}$ & 1 & 99.3149 & 1.57 & ns \\
\hline $\mathrm{E} \times \mathrm{Su}$ & 1 & 279.8064 & 1.79 & $\mathrm{~ns}$ \\
\hline $\mathrm{Z} \times \mathrm{Su}$ & 1 & 1124.6408 & 0.66 & $\mathrm{~ns}$ \\
\hline $\mathrm{Si} \times \mathrm{E} \times \mathrm{Z}$ & 1 & 156.3991 & 1.16 & ns \\
\hline $\mathrm{Si} \times \mathrm{E} \times \mathrm{Su}$ & 1 & 63.1326 & 0.47 & ns \\
\hline $\mathrm{Si} \times \mathrm{Z} \times \mathrm{Su}$ & 1 & 1697.5733 & 14.58 & $<0.001$ \\
\hline $\mathrm{E} \times \mathrm{Z} \times \mathrm{Su}$ & 1 & 613.5047 & 2.82 & ns \\
\hline $\mathrm{Si} \times \mathrm{E} \times \mathrm{Z} \times \mathrm{Su}$ & 1 & 217.4537 & 1.61 & ns \\
\hline Residual & 141 & 134.91049 & & \\
\hline Total & 156 & & & \\
\hline \multicolumn{5}{|l|}{ B. Late plantigrades } \\
\hline Site (Si) & 1 & 0.1102 & 2.94 & ns \\
\hline Exposure (E) & 1 & 0.1360 & 0.44 & ns \\
\hline Zone (Z) & 1 & 1.0407 & 1.18 & ns \\
\hline Substratum (Su) & 1 & 2.5455 & 1.16 & ns \\
\hline \multicolumn{5}{|l|}{ Interactions } \\
\hline $\mathrm{Si} \times \mathrm{E}$ & 1 & 0.3079 & 8.21 & $<0.001$ \\
\hline $\mathrm{Si} \times \mathrm{Z}$ & 1 & 0.8825 & 23.53 & $<0.0001$ \\
\hline $\mathrm{Si} \times \mathrm{Su}$ & 1 & 2.2012 & 58.70 & $<0.0001$ \\
\hline $\mathrm{E} \times \mathrm{Z}$ & 1 & 0.1257 & 1.32 & ns \\
\hline $\mathrm{E} \times \mathrm{Su}$ & 1 & 0.0840 & 0.17 & ns \\
\hline $\mathrm{Z} \times \mathrm{Su}$ & 1 & 0.0641 & 0.13 & ns \\
\hline $\mathrm{Si} \times \mathrm{E} \times \mathrm{Z}$ & 1 & 0.4958 & 13.22 & $<0.0001$ \\
\hline $\mathrm{Si} \times \mathrm{E} \times \mathrm{Su}$ & 1 & 0.0953 & 2.54 & ns \\
\hline $\mathrm{Si} \times \mathrm{Z} \times \mathrm{Su}$ & 1 & 0.4782 & 12.75 & $<0.0001$ \\
\hline $\mathrm{E} \times \mathrm{Z} \times \mathrm{Su}$ & 1 & 1.6263 & 25.61 & ns \\
\hline $\mathrm{Si} \times \mathrm{E} \times \mathrm{Z} \times \mathrm{Su}$ & 1 & 0.0635 & 1.69 & ns \\
\hline Residual & 141 & 0.0375 & & \\
\hline Total & 156 & & & \\
\hline
\end{tabular}

greater on algae for 9 of the 10 comparisons, and 6 of these were significant $(p<0.005)$ after Bonferroni adjustment.

Thus, a $100 \%$ cover of substratum, plantigrades tended to be more abundant on algae than on mussels. However, mussels often had greater total cover within a given zone (Table 1). We weighted numbers of plantigrades according to total cover of each substratum in each zone and compared total numbers on each substratum within zones. Of the 12 possible comparisons, 2 were omitted as mussels were not sampled on the low shore of exposed shores. For each size class of recruits, total numbers on mussels were equal to or greater than total numbers on algae in exactly half of the comparisons ( $p<0.005)$. 


\section{DISCUSSION}

The most striking result of this study was that the effects of the factors examined on plantigrade densities were so extremely variable, resulting in significant interactions among factors in most analyses. Often, this did not mean a reversal of effects (e.g. exposure increases densities in one zone, but decreases them in another), but rather that the effect of a factor varied in strength (e.g. exposure increases densities, but more so in some zones than others). The patterns were generally the same for early and late plantigrades, except for the effect of site, which was significant for early, but generally not for late plantigrades. In spite of this extreme variability, there were clear overall trends: (1) Recruitment was synchronised among substrata within a zone, but not among zones and not between sites. (2) There were frequent effects of site and, where this occurred, densities were higher at Diaz Cross than at High Rocks. (3) Zone invariably had significant effects. The high shore always ranked lowest in terms of recruit densities. The mid shore always had densities similar to, or higher than, the low shore. (4) Exposure had significant effects only in the analysis of densities on algae on the low shore (the low shore comparison could not be done for mussels), where densities on exposed shores were greater than on sheltered shores. (5) Densities of recruits on algae usually exceeded densities on mussels. In terms of total numbers, this was partly balanced by greater cover of mussels. Nevertheless, considering the shore as a whole, about $63 \%$ of early recruits $(<1 \mathrm{~mm})$ were found on algae and only $37 \%$ among adult mussels.

\section{Synchrony}

Recruitment events were poorly synchronised between sites, and there tended to be greater synchrony on different substrata within a zone than on the same substratum in different zones. This suggests that larvae arrived as patches or clouds in a zone and settled on all available substrata within that zone, rather than selecting a preferred substratum across different zones. Patchiness of mussel larvae in the water column occurs on scales ranging from $1 \mathrm{~km}$ to $100 \mathrm{~m}$ (McQuaid \& Phillips 2000, McQuaid \& Lawrie 2005) and almost certainly on much smaller scales. This patchiness, combined with local hydrodynamics, probably prevented strong synchrony of recruitment between sites. For late plantigrades, decreases in density can be explained through mortality, but it is more difficult to interpret abrupt increases in density. These may reflect combinations of growth of smaller individuals, secondary settlement of large individuals and sampling error.

\section{Site effects}

Early plantigrade densities were greater at Diaz Cross than at High Rocks; however, this was not generally the case for late plantigrades. Although stochastic events can influence the number of larvae arriving at a shore (Sebens \& Lewis 1985, Phillips 1994), a consistent site effect on early plantigrades is not unexpected. Work on a number of taxa, particularly barnacles, has shown that certain areas can experience lower settlement than others (e.g. Robles 1997, Dudgeon \& Petraitis 2001, Robles et al. 2001) due to either larval availability (lower densities of larvae in the water adjacent to the shore, e.g. Raimondi 1988, Connolly et al. 2001), or to larval delivery and the influence of local hydrodynamics (e.g. Scheltema 1975, Caffey 1985, Connell 1985, Minchinton \& Scheibling 1991, Young et al. 1996, Garrison 1999, McKindsey \& Bourget 2000). The difference in the results for early and late plantigrades presumably reflects differences in post-settlement mortality rates (e.g. Jenkins et al. 2000 for barnacles) as settlement and post-settlement mortality may be affected in different ways by the same factors.

\section{Zone effects}

In most cases, the densities of both size classes were greater on the low and mid shore than on the high shore. Work on a range of algae and sessile invertebrates, including mussels and barnacles, indicates that this is likely to be due to greater submergence time and greater water depth on the lower shore, giving more time for settlement in these zones (Menge 1991, Bertness et al. 1992). The density of adult Perna decreases upshore and, on this coast, densities of juveniles (1 to $15 \mathrm{~mm}$ ) are correlated with adult densities (McQuaid et al. 2000). Appropriate substrata for settlers are rare on the high shore and the lower zones may effectively filter out larvae before they reach the high shore. It is also possible that settlement is uniform across the shore, but that mortality immediately after settlement is greater on the high shore.

\section{Exposure effects}

The effect of wave exposure on mussel recruitment is not clear. McKindsey \& Bourget (2000) found that recruitment to artificial substrata showed a significant positive correlation to maximum wave force at a site, but a significant negative correlation with mean wave force. Petraitis (1991) and Phillips (1994) found that exposure and settler/recruit densities were not related, but Menge (1992) and Robles (1997) found 
greater recruitment of mussels on exposed shores and we too found a clear effect. Densities of both early and late plantigrades on algae were higher at exposed sites, but the effect was pronounced only on the low shore. Menge (1991) found a very similar pattern for barnacles; recruitment was highest at exposed sites on the low and mid shores, but there was no exposure effect on the high shore. Our findings could be due to at least 3 factors: (1) Greater wave action may transport more settlers to exposed shores or influence their behaviour on the shore. (2) Settler densities may partly reflect structural differences in algal beds. On the low shore, Corallina plants were about $15 \mathrm{~mm}$ tall at sheltered shores and 40 to $60 \mathrm{~mm}$ tall at exposed shores. Mussel settlement is influenced by encounter rates of larvae with suitable habitat (Bologna \& Heck 2000) and taller algae may simply trap more settlers. (3) Poor settlement on sheltered low shore zones may be linked to the scarcity of adult mussels. Each of the last 2 factors suggests that the difference between exposed and sheltered low shore zones may be only indirectly linked to exposure, leading to complex effects.

Our sampling design may confound exposure with other sources of spatial variation, as there was only 1 exposed and 1 protected shore at each site so that the effects of exposure cannot strictly be separated from other factors at the scale of site. However, our interpretation of exposure effects is strongly supported by the consistency between sites.

\section{Substratum effects}

Plantigrade densities were generally higher on algae than on mussels and Lawrie \& McQuaid (2001) provide evidence of an association between algal biomass and recruitment of mussels to algae. Some authors have suggested that mussel larvae actively select algae for settlement (Bayne 1964, King et al. 1990); for example, using chemical cues to differentiate between algal species (Dobretsov 1999, Dobretsov \& Wahl 2001). However, mussel spat are more abundant in finelybranched than coarsely-branched substrata, both natural and artificial (Alfaro \& Jeffs 2002), and it has been argued that hydrodynamic processes alone can explain recruitment patterns on scales of $>3 \mathrm{~cm}$ (Bourget \& Harvey 1998). Cáceres-Martínez et al. (1994) suggest that settlement of Mytilus galloprovincialis is a passive process. Contact mucus threads produced by late pediveligers and post-larvae are more likely to snag filamentous surfaces so that algae trap settlers more efficiently than byssus threads, resulting in higher settlement on algae than on adult mussel beds (Lane et al. 1985). Thus, higher recruit densities may simply be due to the larger surface area, or greater architectural complexity of algae. An alternative, and untested, possibility, is differential post-settlement mortality between the 2 substratum types.

The area of each substratum and densities of plantigrades in each zone were used to calculate total recruit numbers on the shore. Of all plantigrades, $63 \%$ were on algae. Most of these (45\% of total) were on articulated coralline algae. This reflects both the high cover of corallines, and the high densities of settlement onto them (Phillips 1994). Settling on algae may be advantageous to juvenile mussels as (1) algae provide a cryptic habitat that may reduce predation (as described for abalone by Shepherd \& Turner 1985), (2) competition between plantigrades and adults would be reduced (Bayne 1964, Petersen 1984), (3) possible filtering of larvae by adults would be avoided (Andre et al. 1993). However, settlement onto algae is only advantageous to the population as a whole if it is followed by secondary settlement onto mussel beds.

Bayne (1964) first described primary and secondary settlement on beds of Mytilus edulis, and subsequently many authors have suggested that mytilid plantigrades may move onto the mussel bed after an initial growth period on algae (Berry 1978, Beckley 1979, Crawford \& Bower 1983, Beukema \& de Vlas 1989, King et al. 1989 1990, McGrath \& King 1991, Cáceres-Martínez et al. 1993, 1994, Pulfrich 1996). However, there is little direct evidence for this (Bohle 1971, Dare 1976, McGrath et al. 1988, King et al. 1990, Lasiak \& Barnard 1995, Gilg \& Hilbish 2000).

Large (>5 mm) Perna perna appear in low numbers on artificial substrata left on the shore for $24 \mathrm{~h}$ (authors' unpubl. data), and even adult mussels remain surprisingly mobile (Paine 1974), but whether large-scale secondary settlement occurs on this coast remains to be demonstrated (Lasiak \& Barnard 1995). Secondary settlement has been described for northern hemisphere shores with large tidal ranges and sub-tidal mussel beds (Bayne 1964, Dare 1976, Lane et al. 1985). Our shores have low tidal ranges (ca. $2 \mathrm{~m}$ ) and powerful wave action, which may make a second pelagic phase not feasible.

Considering nearly two thirds of larvae are found on algae, their fate is important as mussel exploitation by people is intense on the south coast of South Africa (Lasiak \& Dye 1989, Lasiak 1993). Unfortunately, recruitment on the south coast is orders of magnitude lower than on the west coast (Harris et al, 1998), where there is little exploitation, and generally much lower than in other parts of the world (C. D. McQuaid \& T. E. Phillips unpubl. data). Although new beds of Perna perna may be established in years with exceptionally heavy settlement (Berry 1978), mussel populations here are likely to be strongly recruitment limited. This 
will be exacerbated if over half of early plantigrades settle on a substratum where they have no future. Alternatively, if Perna does exhibit secondary settlement, there is a conflict of interests between mussel conservation and commercial harvesting of macroalgae.

Acknowledgements. We are very grateful to S. Radloff in the Department of Statistics and M. Villet for help with the analyses, and especially to T. L. Lindsay for help in the field. We acknowledge with thanks funding provided by Rhodes University and the National Research Foundation. The manuscript was very much improved by the helpful comments of anonymous referees.

\section{LITERATURE CITED}

Alfaro AC, Jeffs AG (2002) Small-scale mussel settlement patterns within morphologically distinct substrata at Ninety Mile Beach, northern New Zealand. Malacologia 44:1-15

Alvarado JL, Castilla JC (1996) Tridimensional matrices of mussel Perumytilus purpuratus on intertidal platforms with varying wave forces in central Chile. Mar Ecol Prog Ser 133:135-141

Andre C, Jonsson PR, Lindegrath M (1993) Predation on settling bivalve larvae by benthic suspension feeders: the role of hydrodynamics and larval behaviour. Mar Ecol Prog Ser 97:183-192

Armonies W, Hellwig-Armonies M (1992) Passive settlement of Macoma balthica spat on tidal flats of the Wadden Sea and subsequent migration of juveniles. Neth J Sea Res 29: 371-378

Bayne BL (1964) Primary and secondary settlement in Mytilus edulis L. (Mollusca). J Anim Ecol 33:513-523

Beckley LE (1979) Primary settlement of Perna perna (L.) on littoral seaweeds on St Croix Island. S Afr J Zool 14(3): 171-174

Berry PF (1978) Reproduction, growth and production in the mussel, Perna perna (Linnaeus), on the east coast of South Africa. Investl Rep Oceanogr Res Inst S Afr 48:1-28

Bertness MD, Gaines, SD, Stephens EG, Yund PO (1992) Components of recruitment in populations of the acorn barnacle Semibalanus balanoides (Linnaeus). J Exp Mar Biol Ecol 156:199-215

Beukema JJ, Dekker R (2005) Decline of recruitment success in cockles and other bivalves in the Wadden Sea: possible role of climate change, predation on postlarvae and fisheries. Mar Ecol Prog Ser 287:149-167

Beukema JJ, de Vlas, J (1989) Tidal-current transport of thread-drifting post larval juveniles of the bivalve Macoma balthica from the Wadden Sea to the North Sea. Mar Ecol Prog Ser 52:193-200

Bohle B (1971) Settlement of mussel larvae Mytilus edulis on suspended collectors in Norwegian waters. In: Crisp DJ (ed) Proc 4th Eur Mar Biol Symp, Cambridge University Press, Cambridge, p 63-69

Bologna PAX, Heck KL (2000) Impacts of seagrass habitat architecture on bivalve settlement. Estuaries 23:449-457

Bourget E, Harvey M (1998) Spatial analysis of recruitment of marine invertebrates on arborescent substrata. Biofouling 12:45-55

Cáceres-Martínez J, Robledo JAF, Figueras A (1993) Settlement of mussels Mytilus galloprovincialis on an exposed rocky shore in Ria de Vigo, NW Spain. Mar Ecol Prog Ser 93:195-198

Cáceres-Martínez J, Robledo JAF, Figueras A (1994) Settlement and post-larval behaviour of Mytilus galloprovincialis: field and laboratory experiments. Mar Ecol Prog Ser 112:107-117

Caffey HM (1985) Spatial and temporal variation in settlement and recruitment of intertidal barnacles. Ecol Monogr 55:313-332

Connell JH (1985) The consequences of variation in initial settlement vs. post-settlement mortality in rocky intertidal communities. J Exp Mar Biol Ecol 93:11-46

Connolly SR, Menge BA, Roughgarden J (2001) A latitudinal gradient in recruitment of intertidal invertebrates in the north eastern Pacific Ocean. Ecology 83:1799-1813

Cowen RK, Lwiza KMM, Sponagule S, Paris CB, Olson DB (2000) Connectivity of marine populations: open or closed? Science 287:857-859

Crawford RJM, Bower DF (1983) Aspects of growth, recruitment and conservation of the brown mussel Perna perna along the Tsitsikamma coast. Koedoe 26:123-133

Dare PJ (1976) Settlement, growth and production of the mussel, Mytilus edulis, in Morecombe Bay, England. Fish Invest (Lond) 28(Ser. 2):1-25

Davies G (1974) A method for monitoring the spatfall of mussels (Mytilus edulis L.). J Conserv Int Explor Mer 36:27-34

Davis AR, Moreno CA (1995) Selection of substrata by juvenile Choromytilus chorus (Mytilidae): are chemical cues important? J Exp Mar Biol Ecol 191:167-180

Dayton PK (1971) Competition, disturbance and community organization: the provision and subsequent utilisation of space in a rocky intertidal community. Ecol Monogr 41: 351-389

Dobretsov SV (1999) Effects of macroalgae and biofilm on settlement of blue mussel (Mytilus edulis L.) larvae. Biofouling 14:153-175

Dobretsov SV, Wahl M (2001) Recruitment preferences of blue mussel spat (Mytilus edulis) for different substrata and microhabitats in the White Sea (Russia). Hydrobiologia 445:27-35

Dudgeon S, Petraitis PS (2001) Scale-dependent recruitment and divergence of intertidal communities. Ecology 82: 991-1006

Erlandsson J, McQuaid CD (2004) Spatial structure of recruitment in the mussel Perna perna at local scales: effects of adults, algae and recruit size. Mar Ecol Prog Ser 267: 173-185

Fuentes J, Molares J (1994) Settlement of the mussel Mytilus galloprovincialis on collectors suspended from rafts in the Ria de Arousa (NW of Spain): annual pattern and spatial variability. Aquaculture 122:55-62

Garrison LP (1999) Vertical migration behaviour and larval transport in brachyuran crabs. Mar Ecol Prog Ser 176: 103-113

Gilg MR, Hilbish TJ (2000) The relationship between allele frequency and tidal height in a mussel hybrid zone: a test of the differential settlement hypothesis. Mar Biol 137: 371-378

Griffiths CL, Hockey PAR (1987) The interactive roles of predation, competition and tidal elevation in structuring mussel populations. S Afr J Mar Sci 5:547-556

Griffiths RJ (1981) population dynamics and growtyh of the bivalve Choromytilus meridionalis (Kr.) at different tidal levels. Estuar Coast Shelf Sci 12:101-118

Harris J, Branch GM, Elliot BL, Currie B, Dye AH, McQuaid CD, Tomalin B, Velasquez C (1998) Spatial and temporal variability in recruitment of intertidal mussels around the 
coast of southern Africa. S Afr J Zool 33:1-11

Hughes RN, Griffiths CL (1988) Self-thinning in barnacles and mussels: the geometry of packing. Am Nat 132: 484-491

Hunt HL, Scheibling RE (1995) Structure and dynamics of mussel patches in tidepools on a rocky shore in Nova Scotia, Canada. Mar Ecol Prog Ser 124:105-115

Hunt HL, Scheibling RE (1998) Spatial and temporal variability of patterns of colonization by mussels (Mytilus trossulus, M. edulis) on a wave-exposed rocky shore. Mar Ecol Prog Ser 167:155-169

Jenkins SR, Aberg P, Cervin G, Coleman RA and 9 others (2000) Spatial and temporal variation in settlement and recruitment of the intertidal barnacle Semibalanus balanoides (L.) (Crustacea: Cirripedia) over a European scale. J Exp Mar Biol Ecol 243:209-225

Jones WE, Demetropoulos A (1968) Exposure to wave action: measurement of an important ecological parameter on rocky shores on Anglesey. J Exp Mar Biol Ecol 2:46-63

Judge ML, Craig SF (1997) Positive flow dependence in the initial colonization of a fouling community: results from in situ water current manipulations. J Exp Mar Biol Ecol 210: 209-222

King PA, McGrath D, Gosling EM (1989) Reproduction and settlement of Mytilus edulis on an exposed rocky shore in Galway Bay, west coast of Ireland. J Mar Biol Assoc UK 69: 355-365

King PA, McGrath D, Britton W (1990) The use of artificial substrates in monitoring mussel (Mytilus edulis L.) settlement on an exposed rocky shore in the west of Ireland. J Mar Biol Assoc UK 70:371-380

Kitching JA, Sloane JF, Ebling FJ (1958) The ecology of Lough Ine. VIII. Mussels and their predators. J Anim Ecol 27:331-341

Lane DJW, Beaumont AR, Hunter JR (1985) Byssus drifting and the drifting threads of the young post-larval mussel Mytilus edulis. Mar Biol 84:301-308

Lasiak TA (1993) The shellfish gathering practises of indigenous people in Transkei: patterns, preferences and perceptions. S Afr J Ethnol 16:115-120

Lasiak TA, Barnard TCE (1995) Recruitment of the brown mussel Perna perna onto natural substrata: a refutation of the primary/secondary hypothesis. Mar Ecol Prog Ser 120: $147-153$

Lasiak TA, Dye AH (1989) The ecology of the brown mussel Perna perna in Transkei, southern Africa: implications for the management of a traditional food resource. Biol Conserv 47:245-257

Lawrie SM, McQuaid CD (2001) Scales of mussel bed complexity: structure, associated biota and recruitment. J Exp Mar Biol Ecol 257:135-161

Lehane C, Davenport J (2004) Ingestion of bivalve larvae by Mytilus edulis: experimental and field demonstrations of larviphagy in farmed blue mussels. Mar Biol 145:101-107

Leonard GH, Levine JM, Schmidt PR, Bertness MD (1998) Flow-driven variation in intertidal community structure in a Maine estuary. Ecology 79:1395-1411

McCulloch A, Shanks AL (2003) Topographically generated fronts, very nearshore oceanography and the distribution and settlement of mussel larvae and barnacle cyprids. J Plankton Res 25:1427-1439

McGrath D, King PA (1991) Settlement of mussels, Mytilus edulis L., on wave-exposed shores in Irish waters: a survey. Proc Roy Irish Acad B 91(4):49-58

McGrath D, King PA, Gosling EM (1988) Evidence for the direct settlement of Mytilus edulis larvae on adult mussel beds. Mar Ecol Prog Ser 47:103-106
McKindsey CW, Bourget E (2000) Explaining mesoscale variation in intertidal mussel community structure. Mar Ecol Prog Ser 205:155-170

McQuaid CD, Lawrie SM (2005) Supply-side ecology of the brown mussel Perna perna: an investigation of spatial and temporal variation in, and coupling between, gamete release and larval supply. Mar Biol 147:955-963

McQuaid CD, Lindsay TL (2000) The effects of wave exposure on growth and mortality rates of the mussel Perna perna: bottom-up regulation of intertidal populations. Mar Ecol Prog Ser 206:147-154

McQuaid CD, Phillips TE (2000) Limited winddriven dispersal of mussel larvae: in situ evidence from the plankton and the spread of the invasive species Mytilus galloprovincialis in South Africa. Mar Ecol Prog Ser 201: 211-220

McQuaid CD, Lindsay JR, Lindsay TL (2000) Interactive effects of wave exposure and tidal height on population structure of the brown mussel Perna perna. Mar Biol 137: 925-932

Menge BA (1976) Organisation of the New England rocky intertidal community: role of predation, competition and environmental heterogeneity. Ecol Monogr 46:355-393

Menge BA (1991) Relative importance of recruitment and other causes of variation in rocky intertidal community structure. J Exp Mar Biol Ecol 146:69-100

Menge BA (1992) Community regulation: under what conditions are bottom-up factors important on rocky shores? Ecology 73:755-765

Menge BA, Farrell TM (1989) Community structure and interaction webs in shallow marine hard-bottom communities: tests of an environmental stress model. Adv Ecol Res 19: $189-262$

Menge BA, Lubchenco J (1981) Community organization in temperate and tropical rocky intertidal habitats: prey refuges in relation to consumer pressure gradients. Ecol Monogr 51:429-450

Menge BA, Sutherland JP (1976) Species diversity gradients: synthesis of the roles of predation, competition and temporal heterogeneity. Am Nat 110:351-369

Menge BA, Sutherland JP (1987) Community regulation: variation in disturbance, competition, and predation in relation to environmental stress and recruitment. Am Nat 130: $730-757$

Menge JL (1974) Prey selection and foraging period of the predaceous rocky intertidal snail, Acanthina punctulata. Oecologia 17:293-317

Minchinton TE, Scheibling RE (1991) The influence of larval supply and settlement on the population structure of barnacles. Ecology 72:1867-1879

Nielsen KJ, Franz DR (1995) The influence of adult conspecifics and shore level on recruitment of the ribbed mussel Geukensia demissa (Dillwyn). J Exp Mar Biol Ecol 188: 89-98

Paine RT (1974) Intertidal community structure: experimental studies on the relationship between a dominant competitor and its principal predator. Oecologia 15:93-120

Petersen JH (1984) Larval settlement behaviour in competing species: Mytilus californianus Conrad and M. edulis L. J Exp Mar Biol Ecol 82:147-159

Petraitis PS (1991) Recruitment of the mussel Mytilus edulis on sheltered and exposed shores in Maine, USA. J Exp Mar Biol Ecol 147:65-80

Phillips TE (1994) Dispersal, settlement and recruitment: their influence on the population dynamics of intertidal mussels. PhD thesis, Rhodes University, Grahamstown

Pulfrich A (1996) Attachment and settlement of post-larval 
mussels (Mytilus edulis L.) in the Schleswig-Holstein Wadden Sea. J Sea Res 36:239-250

Raimondi PT (1988) Rock type affects settlement, recruitment, and zonation of the barnacle Chthamalus anisopoma Pilsburg. J Exp Biol Ecol 123:253-267

Robles CD (1997) Varying recruitment in constant species assemblages: implications for predation theory of intertidal communities. Ecology 78:1400-1414

Robles C, Robb J (1993) Varied carnivore effects and the prevalence of intertidal algal turfs. J Exp Mar Biol Ecol 166:65-91

Robles C, Sweetnam DA, Eminike J (1990) Lobster predation on mussels: shore-level differences in prey vulnerability and predator preference. Ecology 71:1564-1577

Robles D, Alvarado MA, Desharnais RA (2001) The shifting balance of littoral predator-prey interaction in regimes of hydrodynamic stress. Oecologia 128:142-152

Scheltema RS (1975) Relationship of larval dispersal, gene flow and natural selection to geographic variation of benthic invertebrates in estuaries and along coastal regions. Estuarine research, vol 1: chemistry, biology and estuarine system. Academic Press, New York,

Editorial responsibility: Roger Hughes (Contributing Editor), Bangor, UK
Sebens KP, Lewis JR (1985) Rare events and population structure of the barnacle Semibalanus cariousus (Pallas, 1788). J Exp Mar Biol Ecol 87:55-65

Seed R (1969) The ecology of Mytilus edulis L. (Lamellibranchiata) on exposed rocky shores. I. Breeding and settlement. Oecologia 3:277-316

Shepherd SA, Turner JA (1985) Studies on southern Australian abalone (Genus Haliotis). VI Habitat preference, abundance and predators of juveniles. J Exp Mar Biol Ecol 93:285-298

van der Veer HW, Feller RJ, Weber A, Witte JIJ (1998) Importance of predation by crustaceans upon bivalve spat in the intertidal zone of the Dutch Wadden Sea as revealed by immunological assays of gut contents. J Exp Mar Biol Ecol 231:139-157

Westerbom M, Kilpi M, Mustonen O (2002) Blue mussels, Mytilus edulis, at the edge of the range: population structure, growth and biomass along a salinity gradient in the north-eastern Baltic Sea. Mar Biol 140:991-999

Young EF, Bigg GR, Grant A (1996) A statistical study of environmental influences on bivalve recruitment in the Wash, England. Mar Ecol Prog Ser 143:121-129

Submitted: March 22, 2004; Accepted: March 7, 2005

Proofs received from author(s): September 27, 2005 